\title{
Decentralized Agricultural Extension and Social Networks: The Potential for Agricultural Information and Technology Dissemination in Sri Lanka
}

\section{A.M.B.N.Abeysinghe ${ }^{1^{*}}$}

${ }^{1}$ Extension and Training Center,

Department of Agriculture,

Peradeniya, Sri Lanka

\section{Correspondence:}

*ambnabeysinghe@gmail.com

https://orcid.org/0000-0002-3473-6601

DOI: http://doi.org/10.4038/sljae.v3i2.48

\begin{abstract}
Policymakers in Sri Lanka are seeking for cost-effective extension systems due to poor governance and limited budgets of current agricultural extension programs. Recently, there has been increasing interest in social learning as a mean of technology dissemination at a low cost. Therefore, this paper reviews the literature related to social learning and social-network-based agricultural extension (SNBAE) in developing countries to identify its possibility in information and technology dissemination in Sri Lanka. Furthermore, it looks at the present agriculture extension system of the food crop sector in Sri Lanka to clarify the potential of SNBAE for information and technology flow to the grassroot level. The review of the literature shows that SNBAE has positive effects on the effectiveness of knowledge and skill transfer to peers and neighbours. The overview of the agricultural extension systems in food crop sector in Sri Lanka shows that the decentralized agricultural extension system implemented from 1989 failed to bridge the agricultural information and technology gap, especially due to insufficiency of agricultural extension officers at the village level. However, the analysis of agricultural extension system of food crop sector shows that SNBAE has succeeded to some degree in narrowing the information and technology gap between extension officers and rural small-scale farmers.
\end{abstract}

Keywords: Agricultural extension, Information diffusion, Social-network-based agricultural extension 


\section{Introduction}

Agricultural development is widely recognized as a pre-condition for sustainable growth in developing countries. An important element of many agricultural development strategies is the adoption of new technologies (Anderson and Feder, 2007). Slow rate and improper adoption of new technologies in Sri Lankan small-scale farming are key factors for stagnated agricultural productivity, and environmental and health problems (World Bank 2007). There are many reasons for the slow rate and improper agricultural technology adoption. These include the problems of innovations themselves (Feder and Savastano 2006; Suri 2011), policy decisions (Weerahewa 2017), contextual factors (Foster and Rosenzweig 1995; Swanson and Pehu 2004; Anderson and Feder 2007; Suri 2011; Banerjee et al. 2013; Genius et al. 2014; Krishnan and Patnam 2014), strategy of information flow (Anderson and Feder 2007), and bureaucracy of extension agents (Foster and Rosenzweig 1995; Anderson and Feder 2007; Conley and Udry 2010).

In most public agricultural extension systems, extension workers are accountable to their supervisors and are only indirectly responsible to their farmers and producer organizations. Lack of information, and feedback on farmers' needs and priorities inhibit the design of relevant and effective new innovations (Anderson and Feder 2007). Most of the extension services rely on common recommendations, which are unlikely to be relevant for much of the farming populations due to the heterogeneity among smallholders (Suri 2011). These issues, combined with insufficient public funding and political pressure have motivated policymakers to find alternative agricultural extension modalities (World Bank 2015).

Subsequently, many extension scholars (Conley and Udry 2010; Ricker-Gilbert et al. 2008; Kondylis et al. 2017) and development practitioners have focused on assessing the evidence and feasibility of social-networkbased agricultural extension (SNBAE) approaches (Beaman and Dillon 2018). Extension approaches embodying social learning (leaning from peers and neighbours) are called SNBAE and are recognized by various other names such as farmer-led extension, and farmer to farmer extension (Foster and Rosenzweig 1995; Conley and Udry 2010; Feder et al. 2010). A key common feature of these approaches is that they are implemented via farmer-tofarmer information diffusion through 
trained farmers ${ }^{1}$, which creates spaces for farmer "self-learning" and sharing with others. Moreover, SNBAE allow agricultural extension officers to learn from farmers (Ricker-Gilbert et al. 2008; Kondylis et al. 2017). Unlike conventional top-down extension approaches such as the training and visit (T\&V) approach, SNBAE approaches articulate integrating and building of new knowledge on farmers and facilitate the dissemination of knowledge across the agri-food value chain (Takahashi et al. 2020).

Sri Lankan agriculture itself experiences a vicious circle of the slow rate of technology adoption and less sustainable production (World Bank 2007). The agricultural growth performance in Sri Lanka was significantly below its potential in the past decades (Weerahewa 2017). After the decentralization of the agriculture extension system from national to provincial level in 1989 , the government has reformed policies to reignite the agriculture sector's growth. ${ }^{2}$

\footnotetext{
1 Trained farmers receive agricultural trainings from agriculture extension officers and are expected to transfer the information and technology they learned from extension workers to other farmers. 2 A decentralized extension system of Sri Lanka started in 1989, under the 13th Amendment of the Constitution, central government power was devolved to the nine provincial councils. Hence, agricultural extension became a duty of the provincial councils. As a result, the agricultural extension
}

However, the task has proven challenging in the political, economic, and social uncertainties, especially with the country's top-down agricultural extension approach and its demand for a high resource base. The food crop sector is one of the heavily affected sectors of agriculture with decentralization of agriculture extension. ${ }^{3}$ Thus, policymakers started to consider alternative extension approaches to improve the information and technology access to the grassroot level to break out of this low-level equilibrium and move the system into an upward spiral.

Therefore, this paper reviews literature related to social learning and SNBAE in developing countries to identify the potential of the SNBAE approaches on information and technology dissemination at a low cost. Furthermore, especially this paper looking into the use of the SNBAE approaches in decentralized agricultural extension system of the food crop sector in Sri Lanka to identify the pros and cons of the system to clarify the potential of SNBAE to

function of the Department of Agriculture was largely devolved to the Provincial Departments of Agriculture in nine provinces.

3 Food crop sector agriculture extension includes technology transfer for production, and productivity improvement activities for all crops without plantation crops (Tea, Rubber, Coconut) and minor export crops (Cinnamon, Cardamon, Clove, Pepper, Ginger, Turmeric, Coffee, and so forth). 
facilitate information and technology flow to the grassroots level.

\section{Methodology}

In this paper, the literature on the social learning, SNBAE approaches in developing countries were reviewed. Further, potential of SNBAE on information and technology dissemination within the agricultural extension system of food crop sector in Sri Lanka was analysed. First, quantitative and qualitative agricultural extension and economic studies published in between 1990 to 2020 were reviewed to identify the underlying factors that determine or hinder the effectiveness of SNBAE or social learning in information diffusion and technology adoption. Further, successfulness of information and technology dissemination, adoption of new approaches (including reduced pesticides use), and diffusion of new approaches to 'exposed' farmers were assessed. Social learning, farmer to farmer extension, and decentralized extension were the keywords used to search for the articles in, Google Scholar, Science direct, books, university repositories, and archives of government research institutions. The Networked Digital Library of Theses, Dissertations Index to Theses, and the ProQuest dissertation database were also searched.
To identify the potential of SNBAE on information and technology dissemination within the agricultural extension system of food crop sector in Sri Lanka, secondary data of agricultural extension organizations of food crop sector and their practice in SNBAE approaches were collected from published and non-published sources in Sri Lanka during the period from $3^{\text {rd }}$ March 2020 to 20th December 2020. The secondary data was supplemented with primary data collected from focus group discussions. The discussions lasted for one to two hours and included six senior executive officers (Directors), 12 middle level executive officers (Assistant directors and Agronomists) and 36 agriculture service center (ASC) level officers (agriculture instructors and field assistant) of the agricultural extension organizations in food crop sector (Department of Agriculture (provincial and interprovincial) and Mahaweli Authority). These discussions were audio-recorded. In addition, openended interviews were also held with six key informants those who had retired from afore mentioned institutions.

Section 3 briefly summarises key findings from the literature on SNBAE in developing countries and section 4 presents the overview of the agriculture extension system in the food crop sector in Sri Lanka 
and its potential to use SNBAE on information and technology dissemination.

\section{A Review of Social Network-Based} Agricultural Extension

This section reviews the literature on social learning and SNBAE, concentrating on the conditions under which these approaches are effective and how farmer trainers play a role in disseminating information. In addition, this paper reviews the large-scale projects implemented in developing countries on the basis of the SNBAE.

Social contacts are an essential part of everyone's life. If someone's knowledge, attitude, and behaviors affect others' knowledge, attitude, and ultimately behaviour changes, that individual is said to be a socially influential person. The learning process from these influenceable persons or organizations is called social learning (Rogers 1995). A social network-based targeting approach seeks to increase technology adoption and diffusion by taking advantage of a social network among neighbours and peers (Takahashi et al. 2020). It is also called word-of-mouth technology diffusion and awareness or adoption spreads from person to person. This concept is widely used in marketing promotions (Xevelonakis and Som 2012) and it is now becoming popular in agricultural extension because, with today's mass of advertisements on every thinkable media, people get overloaded with product and services information. Considering the variety of offers, it is hard to get an overview and is extremely time-consuming to find an appropriate direction in technology adoption. In this media-dominated world, farmers tend to go back to the very simplest form of getting trusted information by asking friends or neighbours for recommendations and advice. Hence, agricultural extension strategies seek possibilities to use SNBAE approaches.

The basis of SNBAE approaches is the farmer-to-farmer extension, or learning from neighbors and peers, which has been widely documented since the pioneering studies by Conley and Udry (2001) and Foster and Rosenzweig (1995). The concept of farmer-to-farmer extension is widely applied in present agricultural extension where there are limited extension workers at the village level.

The process of learning from other farmers is effective, especially when the information is reliable, more opportunities are available to observe it in practice, and there is no heterogeneity in farming conditions and technological parameters (Munshi 2004; Suri 2011). In such cases, information about early adopters provides appropriate signals 
to others; it increases knowledge about technologies and expected profits, thereby boosting subsequent adoption by others (Bandiera and Rasul 2006).

The common feature of SNBAE is the use of trained farmers as extension agents. These trained farmers are also called contact farmers, and they are trained in specific technology and expected to share their knowledge and experience with other nontrained community members. This method is now widely used in many developing countries, especially in Asia and Africa (Kondylis et al. 2017; Takahashi et al. 2020).

The empirical findings of the trained farmers $^{4}$ performance who were used as extension agents under SNBAE approaches are mixed (Wellard et al. 2013; Maertens 2017; Nakano et al. 2018). Nakano et al. (2018) showed that key farmers are effective in the technology adoption of ordinary farmers in the network, while Maertens (2017) provided evidence that trained farmers play a significant role than ordinary farmers when peer farmers learn about technological characteristics from their learning links in India. Similarly, the lead-

\footnotetext{
${ }^{4}$ There are three types of farmer trainers: (a) those who are at the hub of the agricultural social network, progressive, and take risks with the new innovations, who are often called "key farmers"; (b) those who are progressive and innovative farmers in technology adoption, often knowledgeable and ready to take
}

farmer approach, implemented in subSaharan African countries, showed a positive impact on the uptake of new technologies among fellow farmers (Wellard et al. 2013; Ugochukwu and Chinyelu 2020). Dillon et al. (2018) compared the degree of technological package diffusion by selecting farmer trainers for sorghum in Burkina Faso based on network size and network centrality measured by eigenvector centrality. The results suggest that the network-based targeting approach was more effective in encouraging broader adoption. Beaman and Dillon (2018) also found similar results for the diffusion of compost production technology in Mali, whereas Lee et al. (2019) showed that the network-based targeting approach is not necessarily superior to random selection of entry points to improve the knowledge of other farmers. Nakano et al. (2018) and Shikuku et al. (2019) showed that contact farmer extension is effective in information and technology dissemination to the community level. However, Kondylis et al. (2017) found that, although centrally trained contact farmers significantly adopted the technology, ordinary farmers and non-centrally trained farmers were less

risks of the new innovations (most of the time selected as contact-farmers); and (c) those who have socioeconomic and farm characteristics similar to the majority of farmers in a community (Takahashi et al., 2020). 
likely to adopt the new technologies in rice.

The success of the dissemination of information through trained farmers may depend on the time and resources spent for information transmission and demonstration to other farmers. Normally, the trained farmers do not receive any monetary payments or incentives for this task. However, Shikuku et al. (2019) implanted a field experiment by providing a private reward and they found that leveraging somebody's reputation or social recognition had a positive impact on contact farmers' experimentation and dissemination effort. Furthermore, they showed that the impact was stronger compared to private material rewards treatment.

The SNBAE are recognized to increase females' access to information. Vasilaky (2013) showed that the social networkbased program increased productivity and significantly affected the yields of the poorest performing female farmers compared to the standard training programs in India. Shikuku et al. (2019) showed that, regardless of the gender of the neighbour, the directly trained female contact farmers increased the likelihood of information exchange.

The above review of recent empirical analyses and case studies of the social learning and SNBAE support the hypothesis that SNBAE one of the options for information and technology diffusion to rural subsistence farmers when formal agricultural extension approaches and organizations are weak. In general, it shows that selection of farmer trainers and the type of incentives they received matters for the success of these methods.

\section{Large-Scale Programs of SNBAE Approach}

Since the 1980s, the approach to agricultural extension service delivery has drawn increasingly more on participatory extension methods and most of these methods were based on SNBAE. Some countries implement SNBAE approach as large-scale programs in their extension organizations.

Farmer field school (FFS) is one of the SNBAE programmes implemented in large scale in many developing countries in their agricultural extension organizations. The FFS started as a social-network-based agricultural extension method in a practical way of disseminating knowledge, especially for integrated pest management (IPM) for East Asian rice-based systems in the 1990s (Feder et al. 2004a), and has spread to more than 84 counties in the world (Davis 2006). In regular sessions from planting to harvest, 
groups of farmers observe and analyze their agro-ecosystem and spread their knowledge to neighbours. Therefore, it creates room for speculation and group discussion, leading to a decision on agricultural interventions to be made (Van den Berg and Jiggins, 2007). The FFS programmes have been the focus of many empirical studies (Feder et al. 2004a; Feder et al. 2004b; Tripp et al. 2005; Davis, 2006; Van den Berg and Jiggins 2007; Ricker-Gilbert et al., 2008). However, the results of these studies have been mixed. Ricker-Gilbert et al. (2008) compared the cost-effectiveness of FFS with alternative methods for disseminating integrated pest management practices in Bangladesh. They found that FFS participants were more likely to adopt IPM practices than recipients of messages from field days and agent visits. Feder et al. (2004a) and Feder et al. (2004b) found that although the FFS did not have a significant impact on technological information dissemination to neighbouring farmers, it effectively disseminates the environmental and health information to them. Tripp et al. (2005) provide evidence that FFS has contributed to increasing farmers' skills and lowering insecticide use on rice in Sri Lanka, and they showed that there is little evidence that skills learned are passed to nonparticipants.

The National Agricultural Advisory Services
(NAADS) program in Uganda, being one of the largest national farmer-to-farmer programs, is an innovative public-private extension service delivery approach in Africa. The NAADS promotes the development of farmer organizations and empowers them to procure advisory services through social network-based information disseminating, manage linkages with marketing partners, and conduct demand-driven monitoring and evaluation of advisory services. In particular, it expects farming experience to be shared between group members. Benin et al. (2007) found that the program had a significant and positive impact on the adoption of new crop and livestock enterprises (vanilla, groundnut, goats, bees), modern technology, and postharvest technologies in Uganda. Muwonge and Wallace (2007) showed that NAADS participation increased the value of farm production by $18 \%$ over NAADS nonparticipation in Uganda. However, some studies show that the NAADS program faced practical difficulties in attempting to reflect farmers' priorities in the advice delivered by service providers, even within a nominally demand-driven social network approach (Obaa et al. 2005; Nkonya et al. 2007).

One recent attempt to revolutionize innovation and diffusion processes in rural Africa is the Sub-Saharan African Challenge 
Program. It introduced the Integrated Agricultural Research for Development (IAR4D) approach, in which the central concept is the innovation platform (IP), and decentralization of the local innovation system (ISPC, 2011). This system promotes new innovations by utilizing indigenous knowledge of farmers and farmers' experiences through a participatory framework and interaction between different stakeholders using social network methods. Pamuk et al. (2014a) found that this participatory innovation platform (IP) robustly promotes the adoption of crop management innovations in eight countries of Africa, and Pamuk et al. (2015) showed that the innovation platform is effective in reducing poverty.

The Agriculture Technology Management Agency (ATMA) is another participatory decentralized extension approach implemented in India based on socialnetwork-based agricultural extension approaches at different levels of farmer organizations in the period 1998-2003 (Feder et al. 2010). According to Swanson (2008), the farmer orientation of the ATMA model in India positively affected the motivation and morale of the field extension staff and farmers at the grassroot level.

Hence, large-scale programs of SNBAE show that famer to farmer extension is the base of these programs and they use trained farmers as extension agents. Furthermore, the review shows mixed results of the success of large-scale extension programs in terms of information diffusion to neighbours and peers.

\section{Advantages and Limitations of SNBAE}

Table 1 highlights the advantages, and limitations of SNBAE approaches with potential solutions. Overview of Table 1 shows that SNBAE are effective in the dissemination of information and technology among the members of the network than conventional extension approaches by using the advantage of social capital. However, as indicated in Table 1 there are considerable limitations of SNBAE, such as evasive behaviour, social exclusion, elite capture, and work for different agendas rather than exclusively with extension, which has to be overcome when implementing the SNBAE. In general, Table 1 shows that selection of farmer trainers for the implementation for SNBAE and the frequent monitoring of them are matters for the success of these methods. 
Table 1: Advantages and limitation of SNBAE

\begin{tabular}{|c|c|c|}
\hline Advantages & Limitation & Possible solutions \\
\hline $\begin{array}{l}\text { Create social capital of rural } \\
\text { communities which is helpful in } \\
\text { technology and information } \\
\text { dissemination. }\end{array}$ & $\begin{array}{l}\text { *Less collective action and } \\
\text { evasive behaviour of } \\
\text { farmers (Rogers, 1995) }\end{array}$ & $\begin{array}{l}\text { *Appointment r and } \\
\text { evaluation of contact } \\
\text { farmer }\end{array}$ \\
\hline $\begin{array}{l}\text { It reduces the burden on the } \\
\text { current extension systems } \\
\text { (Conley and Udry, 2001). }\end{array}$ & $\begin{array}{l}\text { *Social exclusion and elite } \\
\text { capture; dealing with part of } \\
\text { the community (Di Falco et } \\
\text { al., 2018). }\end{array}$ & $\begin{array}{l}\text { *Formation of specialized } \\
\text { social groups, such as } \\
\text { groups exclusively for } \\
\text { women (Feder, et al., } \\
\text { 2010). }\end{array}$ \\
\hline $\begin{array}{l}\text { *SNBAE agents are directly } \\
\text { accountable to the members and it } \\
\text { increases information trust } \\
\text { (Foster and Rosenzweig, 1995; } \\
\text { Feder, et al., 2010). }\end{array}$ & $\begin{array}{l}\text { *Insufficient to address the } \\
\text { more specific and localized } \\
\text { issues (Feder, et al., 2010). }\end{array}$ & $\begin{array}{l}\text { * Frequent monitoring and } \\
\text { support to contact farmers. } \\
\text { (Takahashi et al., 2020). }\end{array}$ \\
\hline $\begin{array}{l}\text { *0vercoming the critical issues } \\
\text { afflicting traditional top-down } \\
\text { extension; inadequate human } \\
\text { resources, less consideration of } \\
\text { farmer's needs, and fewer funds } \\
\text { for the agricultural extension. } \\
\text { (Kondylis et al., 2017) }\end{array}$ & $\begin{array}{l}\text { * Appointed contact farmers } \\
\text { may deal with various } \\
\text { farmers' agendas rather } \\
\text { than exclusively with the } \\
\text { extension (Nakano et al., } \\
\text { 2018). }\end{array}$ & $\begin{array}{l}* \text { Considering contact } \\
\text { farmers past behavior, and } \\
\text { frequent monitoring } \\
\text { (Takahashi et al., 2020). }\end{array}$ \\
\hline $\begin{array}{l}\text { * Easy to monitor and evaluation } \\
\text { of information and technology } \\
\text { flow (Feder and Savastano, 2006; } \\
\text { Takahashi et al., 2020). }\end{array}$ & $\begin{array}{l}\text { * Received Incentives or } \\
\text { political pressure could lead } \\
\text { to conflicts of interest in } \\
\text { agriculture extension } \\
\text { (Feder, et al., 2010). }\end{array}$ & $\begin{array}{l}\text { *Appointment of contact } \\
\text { farmers without political } \\
\text { involvement and frequent } \\
\text { evaluation of contact } \\
\text { farmer (Feder, et al., 2010). }\end{array}$ \\
\hline $\begin{array}{l}\text { * Possibility of closely working } \\
\text { with politicians. (Feder, et al., } \\
2010 \text { ). }\end{array}$ & $\begin{array}{l}* \text { Difficulties } \quad \text { in } \\
\text { dissemination site-specific } \\
\text { and advanced technologies }\end{array}$ & $\begin{array}{l}* \text { Creation of an ICT-based } \\
\text { social network group with } \\
\text { extension officers in the } \\
\text { village. }\end{array}$ \\
\hline $\begin{array}{l}\text { * Services related to public-good } \\
\text { nature and become localized with } \\
\text { farmers' experience, norms, and } \\
\text { customs. (Umali and Schwartz, } \\
\text { 1994) }\end{array}$ & & \\
\hline
\end{tabular}

Note: This table explains the positive aspects, limitations, and possible solutions to overcome the limitations of social network-based agriculture extension (SNBAE). 


\section{Applicability of SNBAE in Decentralized Agriculture Extension System in Sri Lanka}

This section discusses the institutional arrangement and its technology and administration flow in the public agricultural extension system of the food crop sector in Sri Lanka to analyze its feasibility to apply SNBAE. Furthermore, it looks into the present use of SNBAE approaches in Sri Lankan agriculture extension.

\section{Overview of Agricultural Extension System in Sri Lanka}

The Sri Lankan agricultural extension advisory service in the food crop sector started as post-independence phenomenon in the Department of Agriculture (DOA). In 1980, with the World Bank assistance, the Training and Visit (T\&V) extension system was adopted resulting in a major expansion of human resources within the extension system (Wijeratne 1988) (Appendix 1). However, this system was drastically changed with the transfer of 2,400 villagelevel extension workers (Krushikarma Viyapthi Sevakas (KVS)) to the Ministry of Public Administration in 1988. When the government passed the 13th Amendment to the Constitution in 1989, it devolved primary responsibility for crop and livestock extension to the nine provinces.
Thus, Sri Lanka retains a highly complex fragmented extension system, in which most elements work independently, and most units pursue a traditional, top-down, supplydriven approach to extension activities. Figure 1 provides an overview of the different extension agencies active in the food crop sector in Sri Lanka through the different ministries, illustrating the high level of fragmentation.

These organizations practice traditional extension approaches, which mostly use "one size fits all approach" for technology dissemination (Conley and Udry 2001). Due to highly fragmented nature of institutions and their traditional top-down extension approach failed to influence the diverse socio-economic and institutional environments faced by farmers and to empower them to become problem-solving decision-makers.

\section{Provincial Agriculture Extension System}

Nine Provincial Departments of Agriculture (PDOAs) have primary responsibility for implementing extension activities for the major food crops in Sri Lanka at provincial level. The typical organizational structure of the provincial agriculture department is shown in Figure 2. High political involvement, weak coordination with national agricultural policies, low funding 
for agricultural extension, and smaller numbers of village-level officers are some of the critical issues in the provincial agricultural extension system (World Bank,

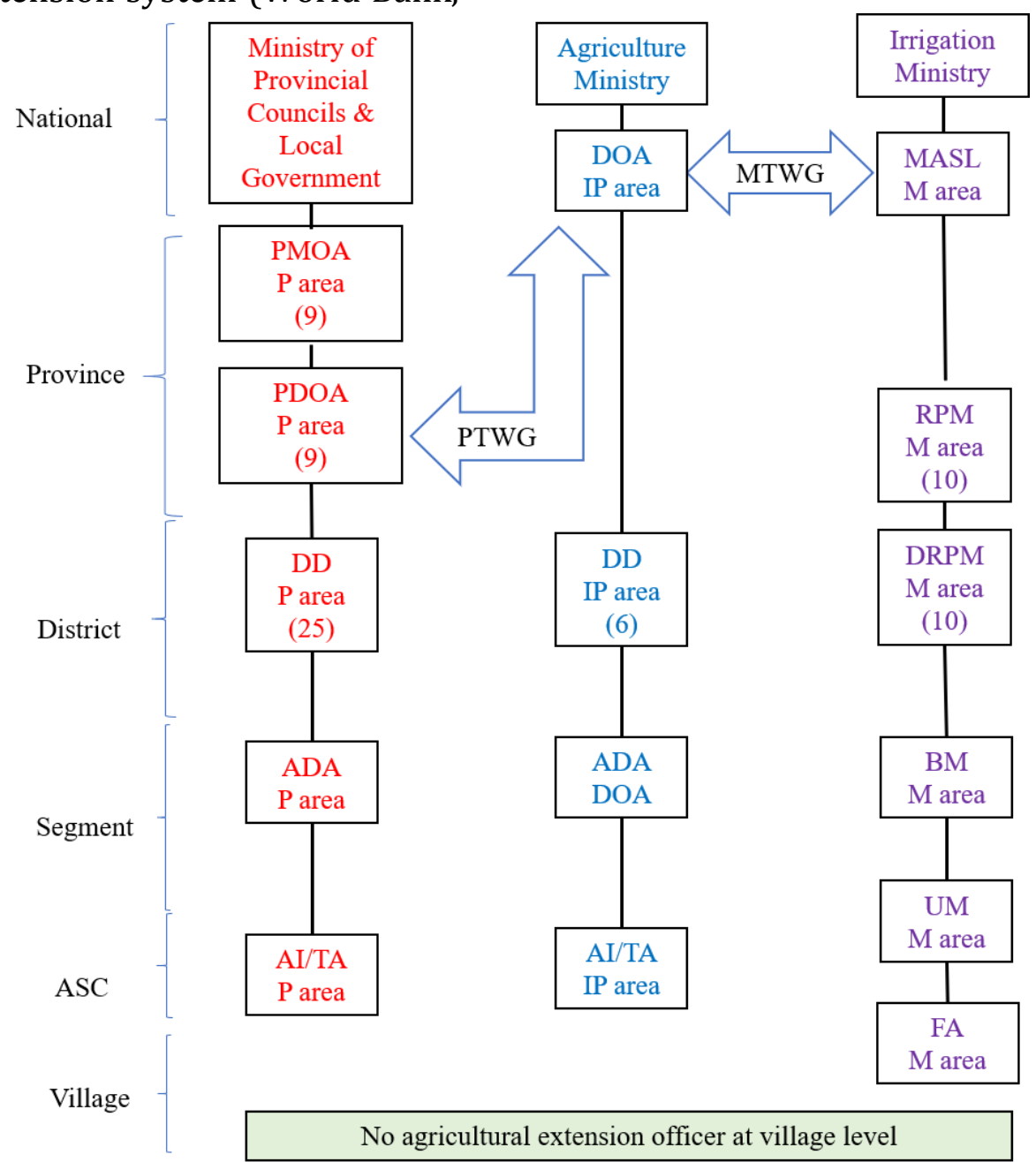

Figure 1: Key public institutions involved in agricultural extension system of food crop sector

Note: PMOA: Provincial ministry of Agriculture, PDOA: Provincial Department of Agriculture, DOA: Department of Agriculture, MASL: Mahaweli Authority, ASC:Agriculture Service Centers, DD: Deputy Director, ADA: Assistant Director, AI Agriculture Instructor, TA: Technical Assistant, RPM: Residential Project Manager, BM: Block Manager, UM: Unit Manager, FA: Field Assistant, Parea: Provincial area, IP: Inter-province area, M area: Mahaweli area. PTWG: Provincial Technical Working Group, MTWG: Mahaweli Technical Working Group. Regular numbers in the brackets refer to units.

is a mixed method of "Training and Visit" (T\&V) and conventional approaches.

Figure 2 illustrates how the flow of coordination and information flow is organized within the provincial extension system. As indicated in Figure 2, the bottom
2007; Ministry of Agriculture, 2019). However, these departments also practice a highly top-down extension approach, which 


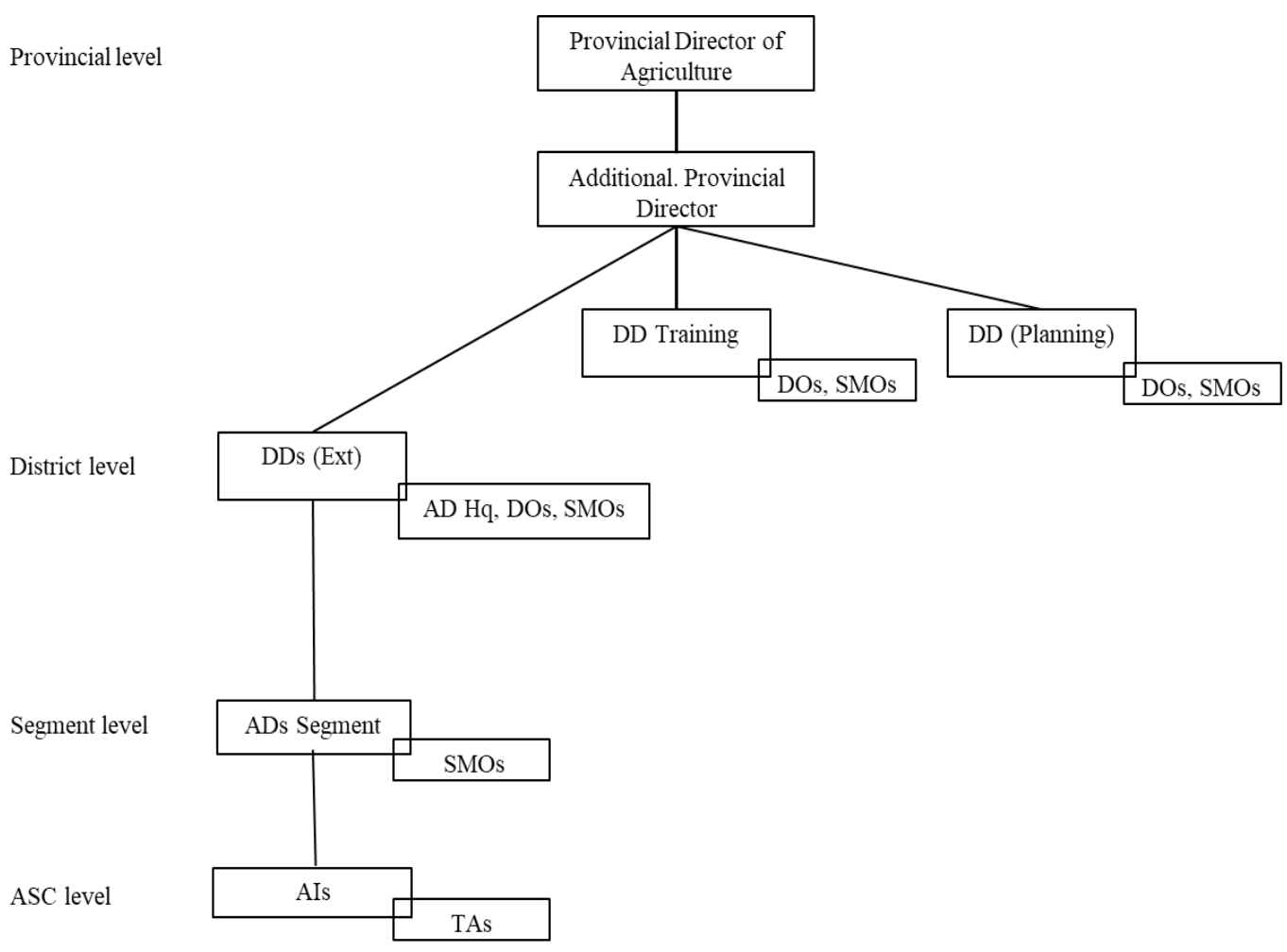

Figure 2: Organizational framework of provincial agricultural extension system in 2019

Note: DD: Deputy Director; AD: Assistant Director; AI: Agriculture Instructor; DO: Development Officer; SMO: Subject Matter Officer; TA: Technical Assistant. There are nine provincial departments in the nine provinces.

Source: Author's survey conducted on 3rd March 2020 to 20th December 2020.

failing to involve farmers in the development of technology and practices appropriate to their context.

\section{Organizations of the Interprovincial Extension System}

The DOA (interprovincial) is mandated to carry out research and extension of major food crops under major irrigation schemes. With the devolution of the agricultural extension service in 1989 , the DOA was limited to the interprovincial (IP) areas controlled by the Extension and Training Center (ETC). It covers major irrigation schemes except Mahaweli areas. To provide mass media agricultural extension in islandwide, the National Agriculture Information and Communication Centre (NAICC) was established based on information and communication technology (ICT). It disseminates appropriate agriculture technologies to farming communities and other beneficiaries through electronic, print and social media, developing and implementation of $e$ solutions for agriculture sector.

Figure 3 illustrates the organisational structure of interprovincial agricultural 


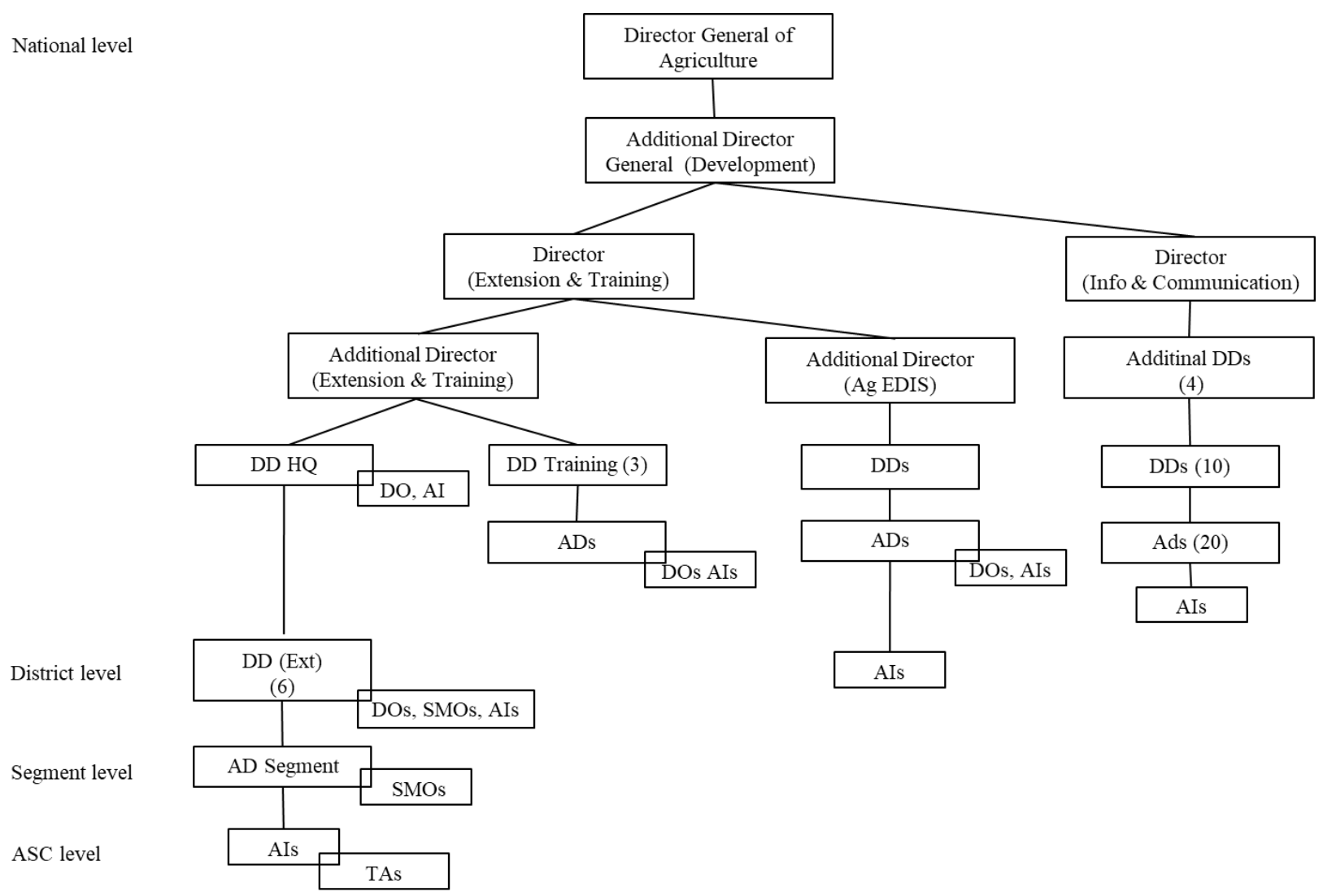

Figure 3: Organizational framework of interprovincial agricultural extension system in 2019

Note: DD: Deputy Director; HQ: Headquarters; AD: Assistant Director; AI: Agriculture Instructor; DO: Development Officer; SMO: Subject Matter Officer; TA: Technical Assistant. There are six interprovincial areas in different districts. Source: Author's survey conducted on 3rd March 2020 to 20th December 2020.

extension system. The DOA is responsible for adoption of new technologies and dissemination of knowledge and skills to deal with changing environment. However, with decentralization of agriculture extension system, DOA had lost it's arm for agricultural extension in the island wide as indicated in Figure1. Furthermore, limited funding for agricultural extension, and the number of village-level agricultural officers are some of the existing barriers to achieve this objective. Therefore, SNBAE provides an opportunity to DOA to expand their extension service with the limited human and fiscal resources.

\section{Agricultural Extension System of Mahaweli Authority of Sri Lanka}

The Mahaweli Authority of Sri Lanka (MASL) has the sole responsibility for agricultural extension within the settlements under the Mahaweli areas. The DOA participates in the biannual Mahaweli Technical Working 


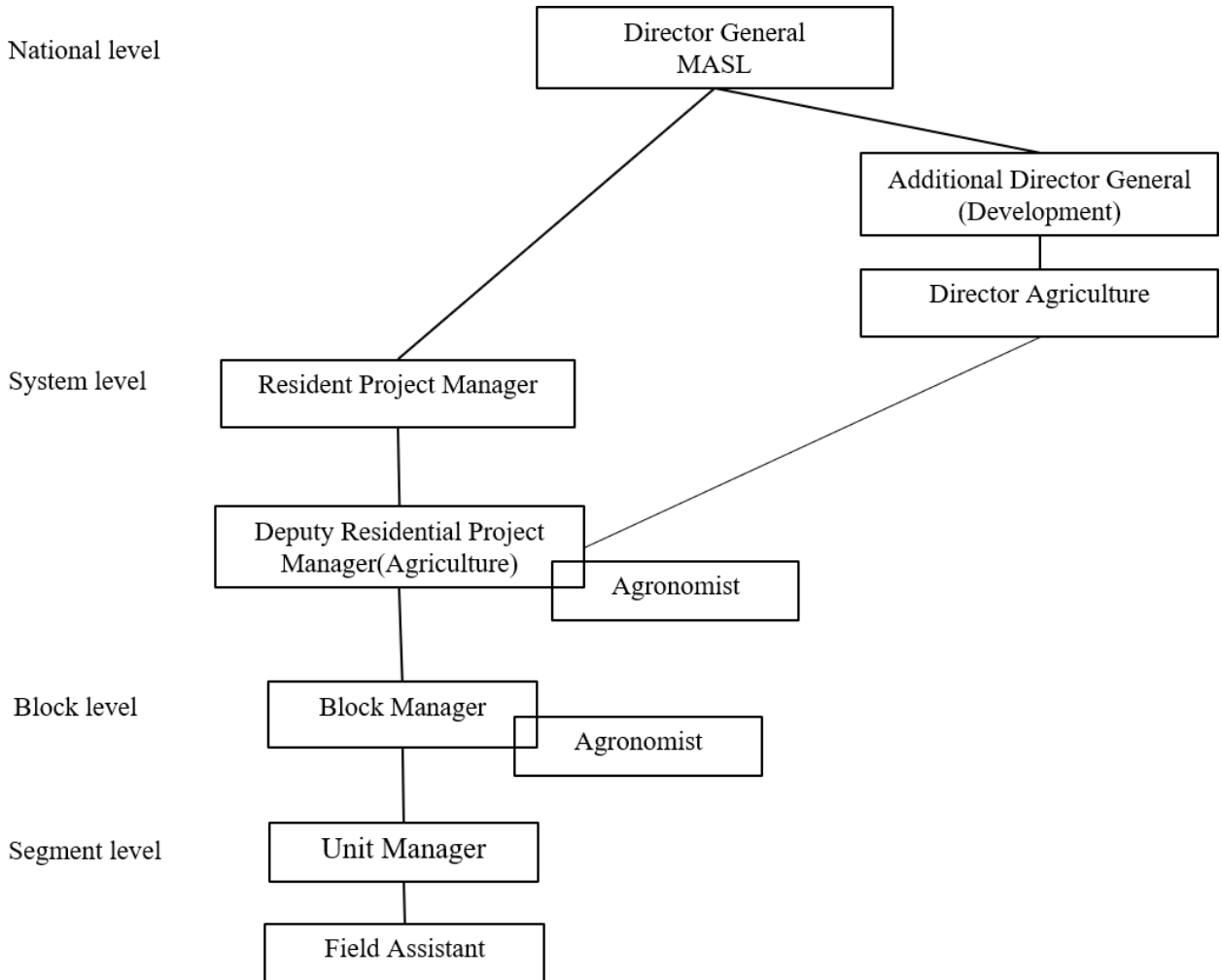

Figure 4: Organizational framework of agricultural extension system of Mahaweli Authority of Sri Lanka in 2019

Note: MASL: Mhawali Authority of Sri Lanka. There are 10 systems island-wide. deputy residential project managers directly coordinate with director agriculture in the head office for agricultural extension activities which is indicated in dotted line

Source: Author's survey conducted on 3rd March 2020 to 20th December 2020.

Group meetings (MTWG); however, other than these meetings, the MASL has limited linkages with other research or extension programs. The Figure 4 shows the organisational structure of MASL. The areas belong to MASL have higher productive capacity and there is opportunity and demand for advance technologies. These facts highlight the potential of practicing SNBAE to disseminate technologies at low cost in MASL areas.
Comparison of the Agricultural Extension System in the Food Crop Sector Before and

\section{After Decentralization}

This section compares the extension services before and after decentration to identify its potential to implement SNBAE in decentralized agriculture extension system in Sri Lanka. The differences in the before and after decentralization are summarized

in Table 2. Decentralized extension system started in 1989, under the 13th Amendment 
Table 2: Before and after comparison of decentralization of agricultural extension systems

\begin{tabular}{|c|c|c|}
\hline Criteria & Before decentralization & After decentralization \\
\hline $\begin{array}{l}\text { Institutes responsible in } \\
\text { agricultural extension }\end{array}$ & $\begin{array}{l}\text { Central government's: } \\
\text { Ministry of Agriculture and } \\
\text { Department of Agriculture }\end{array}$ & $\begin{array}{l}\text { Provincial: PDOA for provincial areas } \\
\text { (nine) } \\
\text { Central government: inter-provincial } \\
\text { areas (six) } \\
\text { Mahaweli Authority: Mahaweli areas } \\
\text { (ten) }\end{array}$ \\
\hline Agricultural extension approach & T\&V approach (Figure 5) & $\begin{array}{l}\text { No clear approach, mixture of "T\&V" } \\
\text { and "Conventional Technology Transfer" } \\
\text { (Figure 6) }\end{array}$ \\
\hline Line of command up to farmer level & Single & $\begin{array}{l}\text { Mixed with the provincial and central } \\
\text { governments }\end{array}$ \\
\hline Availability of village level officer & Available: "KVS" & Not available: ASC level officer - "AI" \\
\hline $\begin{array}{l}\text { Lowest level officers to household } \\
\text { ratio }\end{array}$ & 1: less than $750 \mathrm{HHs}$ & 1: more than $3500 \mathrm{HHs}$ \\
\hline $\begin{array}{l}\text { Way of extension workers make } \\
\text { field visits }\end{array}$ & $\begin{array}{l}\text { Fixed schedule known to all } \\
\text { farmers- Bi-weekly } \\
\text { programmed }\end{array}$ & $\begin{array}{l}\text { No fixed schedule; their own selection } \\
\text { or farmers' requests-Monthly advance } \\
\text { program }\end{array}$ \\
\hline Commitment of officers & High & Low \\
\hline Supervision of field level officers & Easy: Bi-weekly program & $\begin{array}{l}\text { Very difficult: Advance program } \\
\text { changed }\end{array}$ \\
\hline $\begin{array}{l}\text { Update the technical know-how of } \\
\text { officers }\end{array}$ & Regular training & No schedule training \\
\hline Technical coordination & $\begin{array}{l}\text { RTWGs: Functional body } \\
\text { (Figure 5) }\end{array}$ & $\begin{array}{l}\text { PTWGs and MTWG: No coordination } \\
\text { (Figure 6) }\end{array}$ \\
\hline $\begin{array}{l}\text { Political pressure for non- } \\
\text { agriculture activities }\end{array}$ & Low or no & High \\
\hline $\begin{array}{l}\text { Funding differences for the } \\
\text { extension }\end{array}$ & Central government & $\begin{array}{l}\text { Differences in Province, Interprovince } \\
\text { Mahaweli areas }\end{array}$ \\
\hline
\end{tabular}

Note: Decentralization took place in the year 1989. T\&V system: Training and Visit system, KVS:" Krushi Viyapthi Sevaka", AI: Agriculture Instructor, HHs: Households, RTWGs: Reginal Technical Working Group, PTWG: Provincial Technical Working Group, MTWG:Mahavali Technical Working Groups

of the Constitution and central governance power was devolved to the nine provincial councils. Hence, agricultural extension became the main duty of the provincial councils. The T\&V extension approach was the main approach practiced before 
decentralization and it was introduced in 1978 with World Bank assistance to improve the management and efficiency of extension systems, and ended in 1989 as indicated in Table 2. Figure 5 shows the information diffusion and administration flow of the $\mathrm{T} \& \mathrm{~V}$ system up to the village level and it shows that at the bottom of the hierarchy there were village extension workers (KVS). Usually KVS provided their service to 700-800 farming families, with "contact farmers" where contact farmers transfer information to other farmers in the village using their social network.

With the abolishment of field-level KVSs in the decentralized system in 1989, technology and agricultural information diffusion to farmers became the responsibility of Agriculture Instructors (AI) who were stationed in the Agrarian Service Centers ${ }^{5}$. Figure 6 shows the information flow and administration flow of the decentralized system up to the village level of the food crop sector. As indicated in Table 2 and Figure 6, information diffusion to a large number of farming families become a task of AIs and this number ranged fom3,500 to 7,000 farm families in most of the areas. As a result of this shortage of human resources and nonexistence of agricultural

${ }^{5}$ Although the government had appointed village-level
agriculture research and production assistants (ARPAS) under the Department of Agrarian Development in 1994, extension approach, extension system failed to achieve its main objective of farm productivity improvements. For an example, Figures 7 and 8 provide information on rice production in different years in the 11-year gap (from 1967 to 2019) to compare productivity degradation in rice from before and after decentralized system.

As shown in Figure 8 the substantial reduction in rice productivity might be due to the decentralization of extension system.

Therefore, it can be suggested that there is an avenue for SNBAE to improve the agricultural information dissemination and technology adoption of farmers by overcoming the problem of 'one size fits all' technology diffusion approach.

\section{Experience of SNBAE in Sri Lanka}

In this section focuses exclusively on the practical experience of SNBAE and its successfulness on 'sustainability' of technology adoption and information dissemination

Sri Lankan agriculture has a long history of use of trained farmers as agricultural extension agents with the introduction of the $T \& V$ approach in 1980 .

they were not directly involved in agricultural extension (Ministry of Agriculture (2019)). 


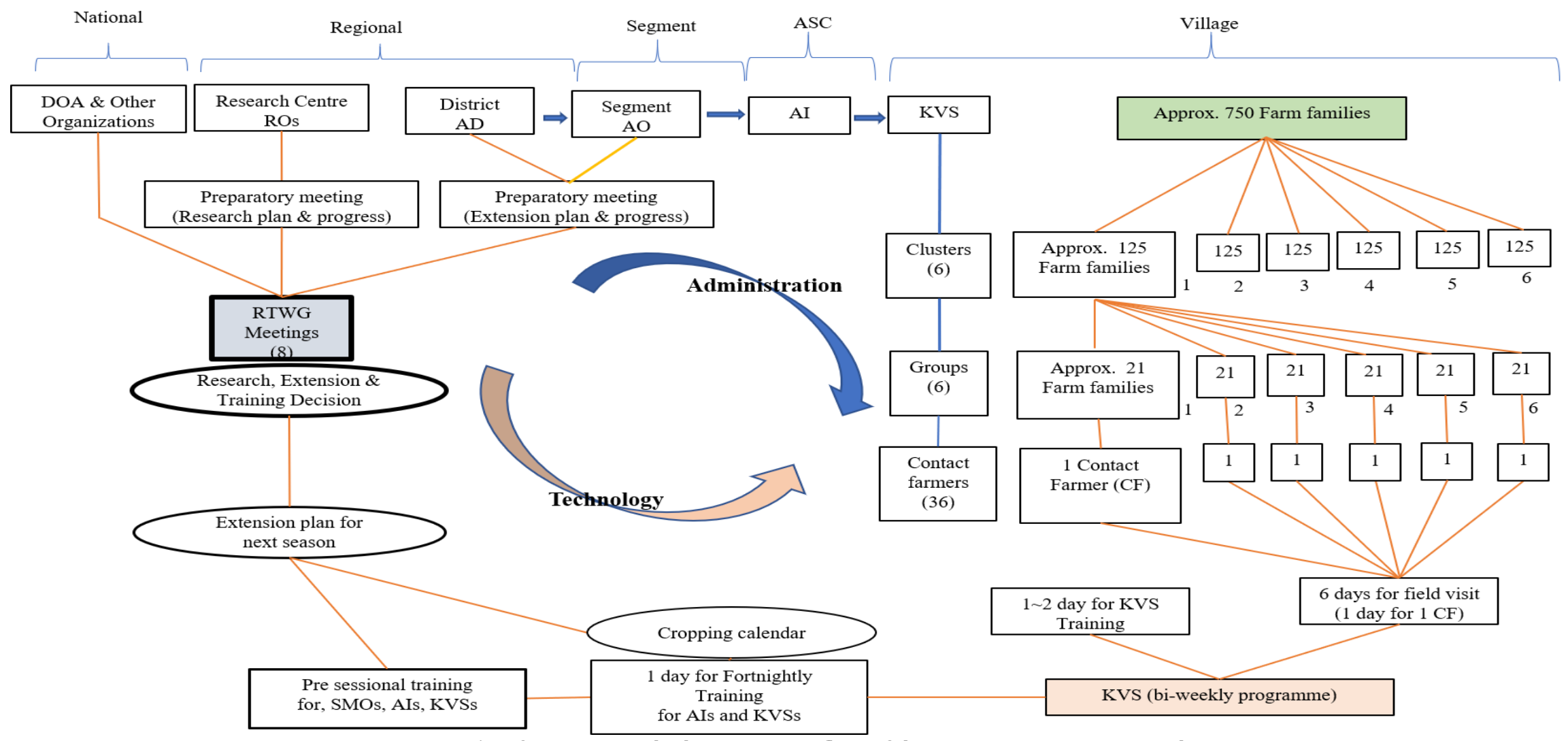

Figure 5: Information and administration flow of the Training \& Visit approach in 1988

Note: DOA: Department of Agriculture, ROs: Research Officers, AD: Assistant Director, AO: Agriculture Office, AI: Agriculture Instructor, KVS: "Krushi Viapthi Sevaka," RTWG: Regional Technical Working Group. KVS is a village-level officer, and one officer provides agricultural extension facilities to less than 750 farmers through groups, clusters, and contact farmers (Abeywardena 1984)

Source: Author's survey conducted on 3rd March 2020 to 20th December 2020. 


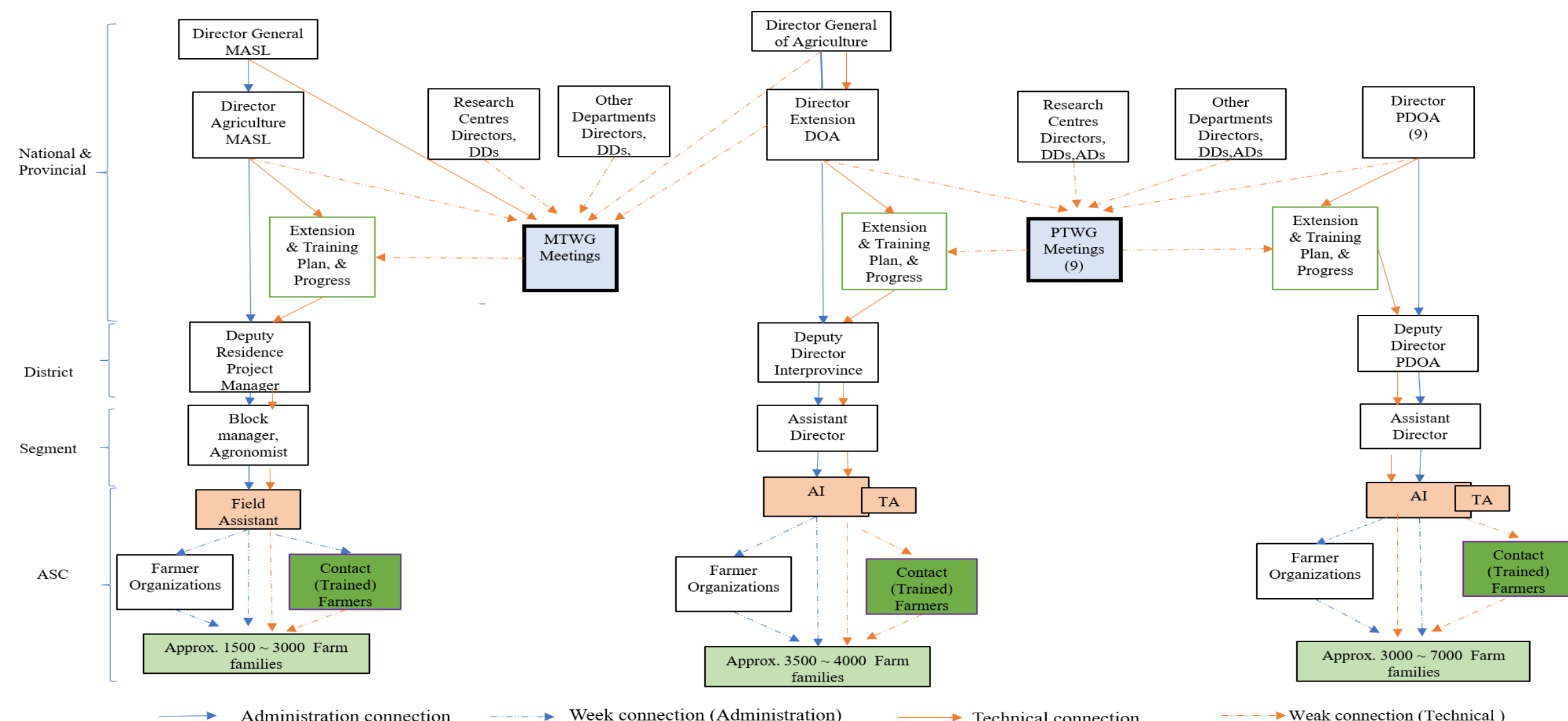

Figure 6: Technology (Information) and administration flow of in 2019 of decentralized system

Note:MASL: Mhawali Authority of Sri Lanka, DOA: Department of Agriculture; DD: Deputy Director; AD: Assistant Director; PDOA: Provincial Department of Agriculture; AI, Agriculture Instructor; TA, Technical Assistant; MTWG: Mahawal Technical Working Group, PTWG: Provincial Technical Working Group. There is no village-level officer or AI for provincial interprovincial areas, and the Field Assistants for Mahaweli areas are the lowest level. Key farmers, contact farmers, and farmer organizations are used as extension agents. Source: Authors' creation from various sources. 


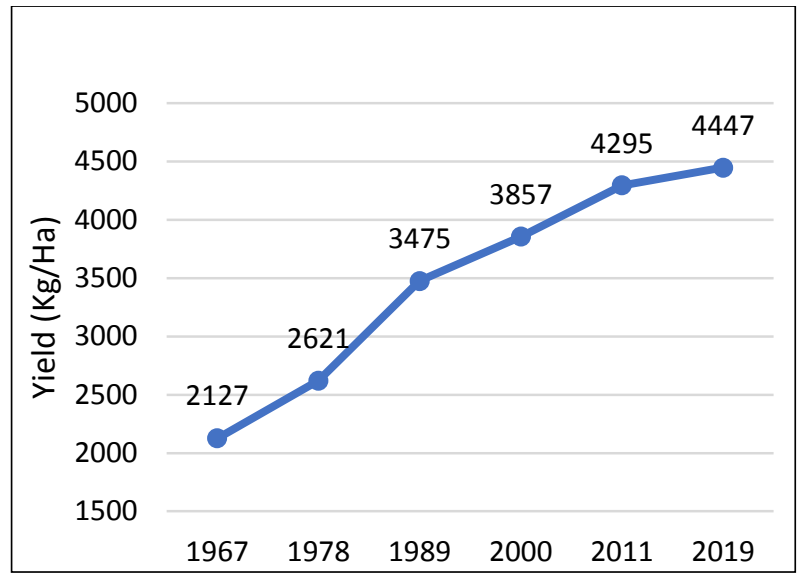

Figure 7: Paddy yields in different years Source: Department of Census and Statistics (various years), Sri Lanka

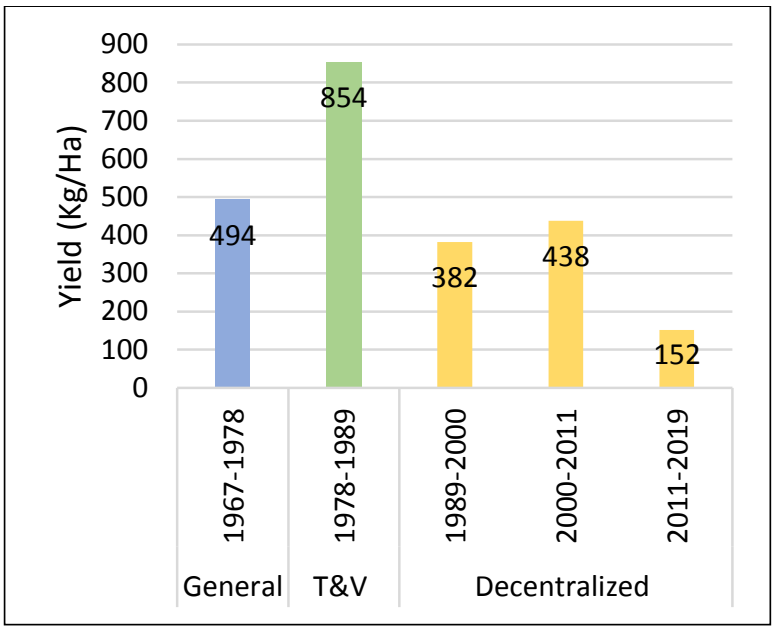

Figure 8: Paddy yield increments under different extension approaches

Source: Department of Census and Statistics (various years), Sri Lanka

With an increased demand for agricultural information and the reduced capacity of extension systems, many extension providers had been using trained farmers as extension agents. Figure 5 shows how trained (contact) farmers were used for technology and information dissemination in the $\mathrm{T} \& \mathrm{~V}$ approach. In general, six to eight contact farmers (trained farmers) in a village were assigned to an extension worker (KVS) in the 1980s (Wijeratne 1988) and these contact farmers were largely used to disseminate new technologies to other farmers with their social network as practical demonstrations in the field. This method is frequently used in decentralized systems with a limited number of extension officers at the village level.

Result demonstrations managed by extension workers with trained farmers are one of the main social network-based agricultural extension tools used in the present agricultural extension (Department of Agriculture 2018).

The demonstration of new technology experiments by the contact farmer improved other farmers' ability to apply the technology, reduced uncertainty about technology attributes, and created certain expectations about returns (Conley and Udry 2001; Nakano et al. 2018). Therefore, it is likely to increase the trialing and continued adoption of the technology in case expectations are met by the farmers. Depending on the level of participation of contact farmers' neighbours and peers in the demonstration trial, this intervention entails an element of learning-bydoing, because it increases awareness of certain technology attributes and economic gain (most importantly, yield potential).

One recent successful example of SNBAE is the popularization of the adoption of hybrid varieties and their management practices for maize. In this extension approach, hybrid seed, 
planting space, fertilizer application, weed management, and post-harvest management were demonstrated to contact farmers with field demonstrations from 2005 to 2010 (Department of Agriculture 2019). Figure 9 presents the evidence associated with the success of this program, and it contributed to a considerable increase in the yield of maize and the cultivated extent.

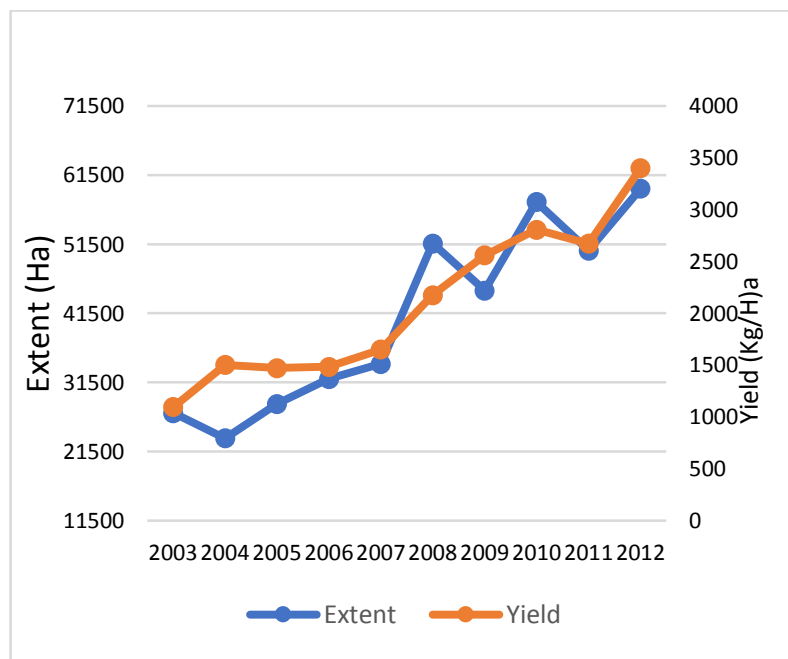

Figure 9: Maize yield and cultivated extent from 2003 to 2012

Source: Department of Census and Statistics (various years), Sri Lanka

Though it is difficult to conclude that the yield gain has been a result of agricultural extension, there was evidence that agriculture extension activities contributed to this achievement (Department of Agriculture 2019). ${ }^{6}$ In addition, the contact farmers and field demonstration methods were intensified through a special program called "Yaya,"

\footnotetext{
${ }^{6}$ Although there is no experimental evidence to prove the succusses of field demonstrations on information and technology dissemination under Sri Lankan condition, Nakano et al. (2018) shows that trained farmers and the demonstrations managed by them are effective in the technology adoption of ordinary farmers in Tanzania.
}

implemented from 2000 to 2007 , to increase national rice production (Wanigasundera 2015). The outcome of these extension efforts after seven years had partially contributed to an increase in the national rice yield up to $4.3 \mathrm{t} / \mathrm{ha}$, as indicated in Figure 10 (Department of Census and Statistics varies years). ${ }^{7}$

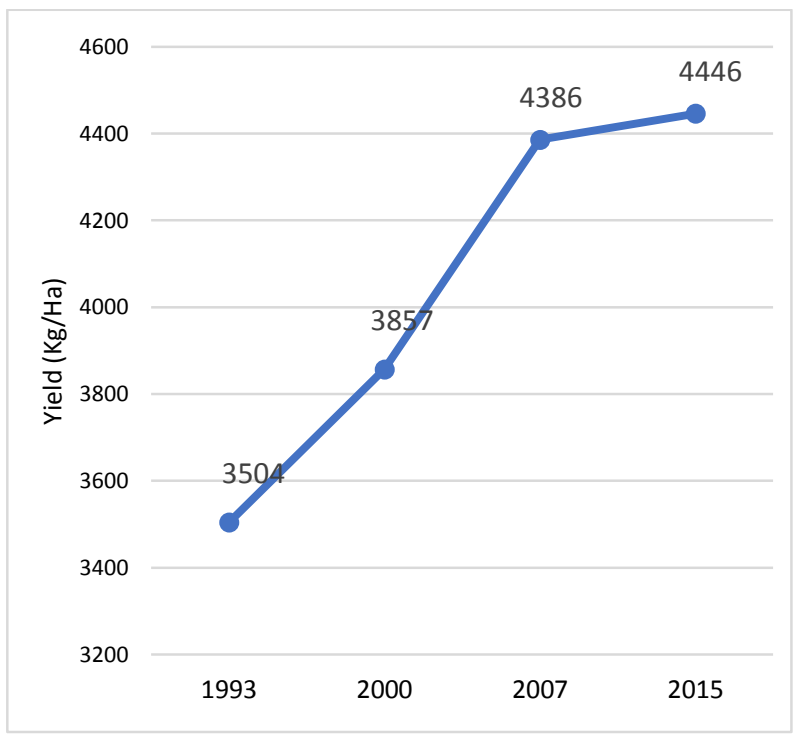

Figure 10: Rice yield from 1993 to 2015

Source: Department of Census and Statistics (various years), Sri Lanka

Field days are another commonly used farmer-to-farmer extension method in agricultural extension. Normally, it involves a large group of discussions of researchers and extension workers to make in-depth contact with farmers. Usually, field days are organized with demonstrations of contact farmers, and it is a single or multiple-day

\footnotetext{
${ }^{7}$ Departments of Agriculture implemented 3116 highyielding Yaya demonstrations in interprovincial areas from the year 2001to 2007 with 41896 farmers. In those Yaya demonstrations average yield has been increased from $3.97 \mathrm{Mt} / \mathrm{ha}$ to $4.85 \mathrm{Mt} / \mathrm{ha}$. (Department of Agriculture, varies years)
} 
event in which presentations and discussions are held in farmer fields about different topics. In this event, farmers learn from discussions with other farmers and observe new technologies in practice. One of the best recent examples for field-days conducted to disseminate technical information to farmers is the Parachute Field Establishment technology of paddy introduced since 2009 (Department of Agriculture various years). In this method, contact farmers establish Parachute demonstrations with the help of agricultural extension, and two field days are conducted at the field establishment time and harvesting time to exchange technical information. As an example, Department of Agriculture established 3,497 Parachute demonstrations in interprovincial areas and 1,896 field days were conducted in above demonstrations in 2018 (Department of Agriculture 2019).

Another widely used SNBAE method is integrated pest management (IPM) farmer groups. This system was introduced as a solution to the environmental and health problems caused by misuse of agrochemicals (Wanigasuriya et al. 2007; Bandara et al. 2010; Fonseka et al. 2012). In this system, extension officers continuously work with self-motivated farmer groups in a village. They observe, learn, and analyze their agro-ecosystem, crop management practices, and practice intensive agriculture technologies in regular sessions from planting to harvest. It is expected that the knowledge gained thereby will spread to participants' neighbours. The system was successful in various cropping systems, especially rice and vegetables, and it continues in the present agricultural extension system (Jayasooriya and Aheeyar 2016).

The Department of Agriculture, with other donors (FAO for example), have conducted Farmer Field Schools (FFS) (based on farmer-to-farmer information diffusion) for IPM in rice and other crops from 1995 to 2009. However, FFS appeared to be an expensive intervention both in terms of direct outlays for professional facilitators and the opportunity cost of farmers' time. Moreover, they were overwhelmingly dependent on donor funding rather than on recurrent government expenditure. Therefore, the sustainability of FFS has drastically declined with the limitation of funding to the national extension system (Tripp et al. 2005).

\section{Conclusions and Recommendations}

This paper reviewed the literature related to Social Network Based Agricultural Extension Approaches (SNBAE) in 
developing countries, to identify its possibility in technology and information dissemination. Furthermore, the present agricultural extension system of the food crop sector in Sri Lanka was also considered to clarify the potential of SNBAE for information and technology flow to the grassroot level.

The reviews of recent empirical analyses and case studies of the social network-based agricultural extension support the hypothesis that SNBAE is one of the options for information and technology dissemination to rural small-scale farmers. Farmer extension, using a trained farmer as an extension agent, is a common feature of all these methods. However, the review shows mixed results of success in terms of information dissemination to neighbours and peers. In general, it shows that the selection of farmer trainers and the type of incentive they receive matters for the success of these methods. The review of food crop sector and its extension approaches suggest that the weak extension system is one of the main reasons for the low adoption rate of new technologies in Sri Lanka. In particular, the analysis shows that the devolution of agricultural extension to the provinces in 1989 created a functional disconnect between the national extension unit of the Department of Agriculture and other extension organizations (Provincial Department of Agriculture and Mahaweli Authority of Sri Lanka). Therefore, it created major linkage problems between research and extension systems, and it has caused slow information and technology flow to rural subsistence farmers. The provincial technical working groups (PTWGs) and nonfunctional pre-seasonal training of PTWGs are some of the main evidences of this slow rate of information and technology flow from the research to farmers. Thus, the technology dissemination to the grassroot level from research centers through agricultural extension is highly disconnected and it does not allow the knowledge generated in research to be put into productive use.

Another critical issue found in the review of agricultural extension system in Sri Lanka is that the absence of a village-level extension worker. It also creates a vacuum of information between farmers, extension officers, and researchers. The lowest level extension officers to the farm household ratio of the current operating extension system is $1: 3,500-7,500$ which imposes a huge burden on above officers. This results a considerable technology and information gap between research stations and farmers at village level. Thus, the improved technological packages that can be practiced 
by the farmers to achieve sustainable higher yields, do not reach farmers as expected. Therefore, the decentralized system has created serious problems in extension coverage, limited supervision and evaluation. Thus, most Agriculture Instructors conduct their extension based on their own preferences for resource-rich progressive farmers, which discourages interest and confidence among other farmers.

However, the review of the SNBAE practiced in Sri Lanka shows that although the decentralized system has low village-level extension coverage, there is a possibility of dissemination information and technology using social network-based agricultural extension methods, especially by using farmer trainers (contact farmers, key farmers) and field demonstrations. Therefore, this paper suggests that empirical research on the role and effectiveness of SNBAE and farmer trainers in the dissemination of information and new technologies in a variety of backgrounds is necessary for policy decisions.

\section{Acknowledgement}

I am deeply grateful for the insightful suggestions of Assoc. Prof. Takahiro Ito,
Prof. Koji Yamazaki, and Prof. Takahiro Sato at Kobe University, Japan.

Conflicts of Interest: The author has no conflicts of interest regarding this publication.

\section{References}

Abeywardena, P 1984, A study of agricultural extension experiences in Sri Lanka. Peradeniya, Sri Lanka.

Anderson, J R \& Feder, G 2007, 'Agricultural extension', in Evenson R, Pingali P (Eds.) Handbook of Agricultural Economics. Rome: Elsevier.

Bandara, J M R S, Wijewardena, H V P, Seneviratne \& H M M S 2010, 'Remediation of cadmium contaminated irrigation and drinking water: A large scale approach', Toxicology Letters 198(1): 89-92.

Bandiera, 0, Rasul, I 2006, 'Social networks and technology adoption in Northern Mozambique', Economic Journal 116(514): 869-902.

Banerjee, A, Chandrasekhar, A G, Duflo, E, Jackson, M 0 2013, 'The diffusion of microfinance', Science 341(6144): 1236498.

Beaman, L, Dillon, A 2018, 'Diffusion of agricultural information within social networks: Evidence on gender inequalities 
from Mali', Journal of Development Economics 133(February): 147-161'

Benin, S, Nkonya, E, Oketcho, G, Pender, J L, Nahdy, S, Mugarura, S, Kayobyo, G 2007, 'Assessing the impact of the national agricultural advisory services (NAADs) in the Uganda rural livelihoods', Available at SSRNhttps://www.ifpri.org/publication/as sessing-impact-national-agricultural-advis ory-services-naads-uganda-rural-livelihoo ds Accessed: September 10,2020.

Conley, T G \& Udry, C R 2010, Learning about a new technology: Pineapple in Ghana', American Economic Review 100(1): 35-69.

Conley, T G \& Christopher, U 2001, Social learning through networks: 'The adoption of new agricultural technologies in Ghana', American Journal of Agricultural Economics 83(3): 668-673.

Davis, K 2006, 'Farmer Field Schools: A boon or bust for extension in Africa?', Journal of International Agricultural and Extension Education 13(1): 92-97.

Department of Agricultures, 2019, 'Agricultural extension and education progress 2000 to 2018', Unpublished manuscript.

Department of Agriculture, 2019, AgStat. Agricultural statistics: Vol. XVI.
Department of Agriculture (various years). Annual Reports. Peradeniya.

Department of Agriculture (various years). Agriculture extension progress reports. Peradeniya.

Department of Census and Statistics (various years). Agricultural statistics of Sri Lanka. Colombo.

Di Falco, S, Feri, F, Pin, P \& Vollenweider, X 2018, 'Ties that bind: Network redistributive pressure and economic decisions in village economies', Journal of Development Economics, 131(November 2017): 123-131.

Dillon, A, Porter, M, Ouedraogo, A 2018, ,Social network targeting of agricultural technology: Adoption, input substitution and yield effects', Selected Paper Prepared for Presentation at the 2018 Agricultural \& Applied Economics Association Annual Meeting Washington, D.C.

Feder, G, Anderson, J R \& Deininger, K 2010, 'Promises and realities of community-based agricultural extension', Agricultural Extension IFPRI Discussion Paper. https:// www.ifpri.org/publication Accessed: Decem ber 17, 2020.

Feder, G, Murgai, R, Quizon, J B 2004a, 'Sending farmers back to school: The impact 
of farmer field schools in Indonesia', Review of Agricultural Economics 26(1): 45-62.

Feder, G, Murgai, R, Quizon, J B 2004b, 'The acquisition and diffusion of knowledge: The case of pest management training in Farmer Field Schools, Indonesia', Journal of Agricultural Economics 55(2): 221-243.

Feder, G, Savastano, S 2006, 'The role of opinion leaders in the diffusion of new knowledge: The case of integrated pest management', World Development 34(7): 1287-1300.

Fonseka, S, Jayasumana, C, Jayalth, K, Amarasinghe, M, Senanayake, K, Wijwwardana, C, Paranagam, P 2012, Arsenic and hardness in ground water from chronic kidney disease of unknown etiology (CKDU) prevalent areas and non -CKDU prevalent areas in Sri Lanka in Ileperuma O, Pryantha, N, Navaratna A, Yatigammana,, S $\mathrm{K}$, Weragoda, K (Eds.), International Symposium on Water Quality and Human Health, PGIS.

Foster, A D \& Rosenzweig, M R 1995, 'Learning by doing and learning from others: Human capital and technical change in agriculture', Journal of Political Economy 103(6): 1176-1209.

Genius, M, Koundouri, P, Nauges, C \& Tzouvelekas, V 2014, 'Information transmission in irrigation technology adoption and diffusion: Social learning, extension services, and spatial effects', American Journal of Agricultural Economics 96(1): 328-344.

Ispc, C 2011, 'Report of the second external review of the Sub-Saharan Africa Challenge Program (SSA-CP), Rome, Italy', http://www.fao.org/3/i2350e/i2350e00Ac cessed: November 12, 2020.

Jayasooriya, H J C \& Aheeyar, M M M 2016, 'Adoption and factors affecting on adoption of integrated pest management among vegetable farmers in Sri Lanka', Procedia Food Science 6(1): 208-212.

Kondylis, F, Mueller, V \& Zhu, J 2017, 'Seeing is Believing? Evidence from an extension network experiment', Journal of Development Economics 125: 1-20.

Krishnan, P \& Patnam, M 2014, 'Neighbors and extension agents in Ethiopia: Who matters more for technology adoption?', American Journal of Agricultural Economics 96(1): 308-327.

Lee, G, Suzuki, A, Nam, V H 2019, 'Effect of network-based targeting on the diffusion of good aquaculture practices among shrimp producers in Vietnam', World Development 124: http://www.ncbi.nlm.nih.gov/pubmed /104641. Accessed: December 17, 2020. 
Maertens, A 2017, 'Who cares what others think (or do)? Social learning and social pressures in cotton farming in India', American Journal of Agricultural Economics 99(4): 988-1007.

Ministry of Agriculture, 2019, 'Sri Lanka Overarching Agricultural Policy', (Issue August): http://www.agrimin.gov.lk/web/ images/Information_Act/Development/201 9_8_19 Draft_OAP.pdf. Accessed: April 29th, 2021.

Munshi K (2004). 'Social learning in a heterogeneous population: Technology diffusion in the Indian Green Revolution', Journal of Development Economics 73(1): 185-213.

Muwonge A \& Wallace S 2007, 'Local Government financing and provision in an institutionally constrained decentralized system: The case of agricultural extension in Uganda', Dissertation. Georgia State University.

Nakano Y, Tsusaka T W, Aida T \& Pede V 0 2018, 'Is farmer-to-farmer extension effective? The impact of training on technology adoption and rice farming productivity in Tanzania', World Development 105: 336-351.

Nkonya, E, Okecho, G, Pender, J, Nahdy, S, Mugarura, S, Kato, E \& Kayobyo, G 2007,
Assessing the impact of the National Agricultural Advisory Services (NAADS) in the Uganda rural livelihoods', https://www.ifpri.org/publication Accessed. December 17, 2020.

Obaa, B, Mutimba, J \& Semana, A R 2005, 'Prioritizing farmers' extension needs in a publicly funded contract system of extension: A case study from Mukono District, Uganda', https://www.odi.org/ publications/4250 Accessed. December 17, 2020.

Pamuk, H, Bulte, E \& Adekunle, A A 2014a, 'Do decentralized innovation systems promote agricultural technology adoption? Experimental evidence from Africa', Food Policy 44: 227-236.

Pamuk, H, Bulte, E, Adekunle, A \& Diagne, A 2015, Decentralised innovation systems and poverty reduction: Experimental evidence from Central Africa', European Review of Agricultural Economics 42(1): 99-127.

Ricker-Gilbert, J, Norton, G W, Alwang, J, Miah, M \& Feder, G 2008, Cost-effectiveness of alternative integrated pest management extension methods: An example from Bangladesh', Review of Agricultural Economics 30(2): 252-269.

Rogers, E M 1995, 'Diffusion of Innovations', (3rd ed.). New York: Free Press; London. 
Shikuku, K M, Pieters, J, Bulte, E \& Läderach, P 2019, 'American Journal of Agricultural Economics' 101(4): 1164-1180.

Suri, T 2011, 'Selection and comparative advantage in technology adoption. Econometrica', 79(1): 159-209.

Swanson, B E 2008, 'Global Review of Good Agricultural Extension and Advisory Practices', Food and Agriculture Organization of the United Nations.

Swanson, J \& Pehu, E 2004, 'Demand- driven approaches to agriculture extension, case studies of international initiatives in Rivera $W^{\prime}$, in Alex G (ed.) Agriculture and Rural Development Discussion. Washington, DC: World Bank: paper 10 on Extension Reform for Rural Development (Vol. 3).

Takahashi, K, Muraoka, R, Otsuka, K 2020, Technology adoption, impact, and extension in developing countries' agriculture: A review of the recent literature. Agricultural Economics 51(1): 31-45.

Tripp, R, Wijeratne, M \& Piyadasa, V H 2005, 'What should we expect from farmer field schools? A Sri Lanka case study', World Development 33(10): 1705-1720.

Umali, D \& Schwartz, L 1994, 'Public and Private Agricultural Extension', The World Bank Report. Washington, DC.
Ugochukwu, N C \& Chinyelu, N I 2020, 'A Review of Agricultural Extension and Advisory Services in sub- Saharan African Countries: Progress with Private Sector Involvement', Preprints: 2020080294.

Van den Berg, H, Jiggins, J 2007, Investing in farmers-the impacts of Farmer Field Schools in relation to integrated pest management. World Development 35(4): 663-686.

Vasilaky, K 2013, 'Female social networks and farmer training: Can randomized information exchange improve outcomes?', American Journal of Agricultural Economics 95(2): 376-383.

Wanigasundera, W A D P 2015, 'Status of extension and advisory services in Sri Lanka', https://www.aesanetwork.org/wpcontent/uploads/2018/02/ Accessed: Aug ust 16, 2020.

Wanigasuriya, K P, Peiris-John, R J \& Wickremasinghe, R, Hittarage, A 2007, 'Chronic renal failure in North Central Province of Sri Lanka: An environmentally induced disease', Transactions of the Royal Society of Tropical Medicine and Hygiene 101(10): 1013-1017.

Weerahewa, J 2017, 'Modernizing agriculture in Sri Lanka - Status and challenges in. in Perama-Cahndra A, Hill H, 
Kumar U (Eds.)', The Sri Lankan Economy Charting A New Course. Colombo, Sri Lanka.

Wellard, K, Rafanomezan,a J, Nyirenda, M, Okotel, M \& Subbey, V 2013, 'A review of community extension approaches to innovation for improved livelihoods in Ghana, Uganda and Malawi', Journal of Agricultural Education and Extension 19(1): 21-35. Wijeratne M (1988). Farmer extension and research in Sri Lanka. https://edepot.wur.nl/134644 Accessed: August 16, 2020.

World Bank, 2007, 'Reviving Sri Lanka's Agricultural Research and Extension System: Towards More Innovation and Market Orientation', Colombo, Sri Lanka

World Bank, 2015, Systematic Country Diagnostic. Washington DC.

Xevelonakis, E \& Som, P 2012, The impact of social network-based segmentation on customer loyalty in the telecommunication industry', Journal of Database Marketing and Customer Strategy Management, 19(2):98106.

\section{Appendices}

Table A1: Different varieties rice recommended to cultivate and their yield potential

\begin{tabular}{lcc}
\hline \hline Variety & $\begin{array}{c}\text { Age } \\
\text { (Months) }\end{array}$ & $\begin{array}{c}\text { Yield Potential** } \\
\text { (ton/ha) }\end{array}$ \\
\hline Bg 300 & 3.0 & 7.0 \\
Bg 304 & 3.0 & 7.4 \\
Bg 304 & 3.0 & 8.0 \\
Bg 94-1 & 3.5 & 8.5 \\
BG 350 & 3.5 & 8.0 \\
Bw 351 & 3.5 & 7.0 \\
Bg 352 & 3.5 & 7.0 \\
At 353 & 3.5 & 6.5 \\
Bg 357 & 3.5 & 9.55 \\
Bg 358 & 3.5 & 9.5 \\
Bg 359 & 3.5 & 9.5 \\
Bg 366 & 3.5 & 8.9 \\
Bg 379-2 & 4.0 & 7.5 \\
Bg 403 & 4.0 & 2.5 \\
Bg 400-1 & -5 & \\
Traditional & & \\
\hline \hline
\end{tabular}

Bg:Batalagoda, At:Ambalantota, Bw:Bombuwela, LD:Labuduwa

** Yield potential at respective breeding stations Source: Department of Agriculture (various years) 


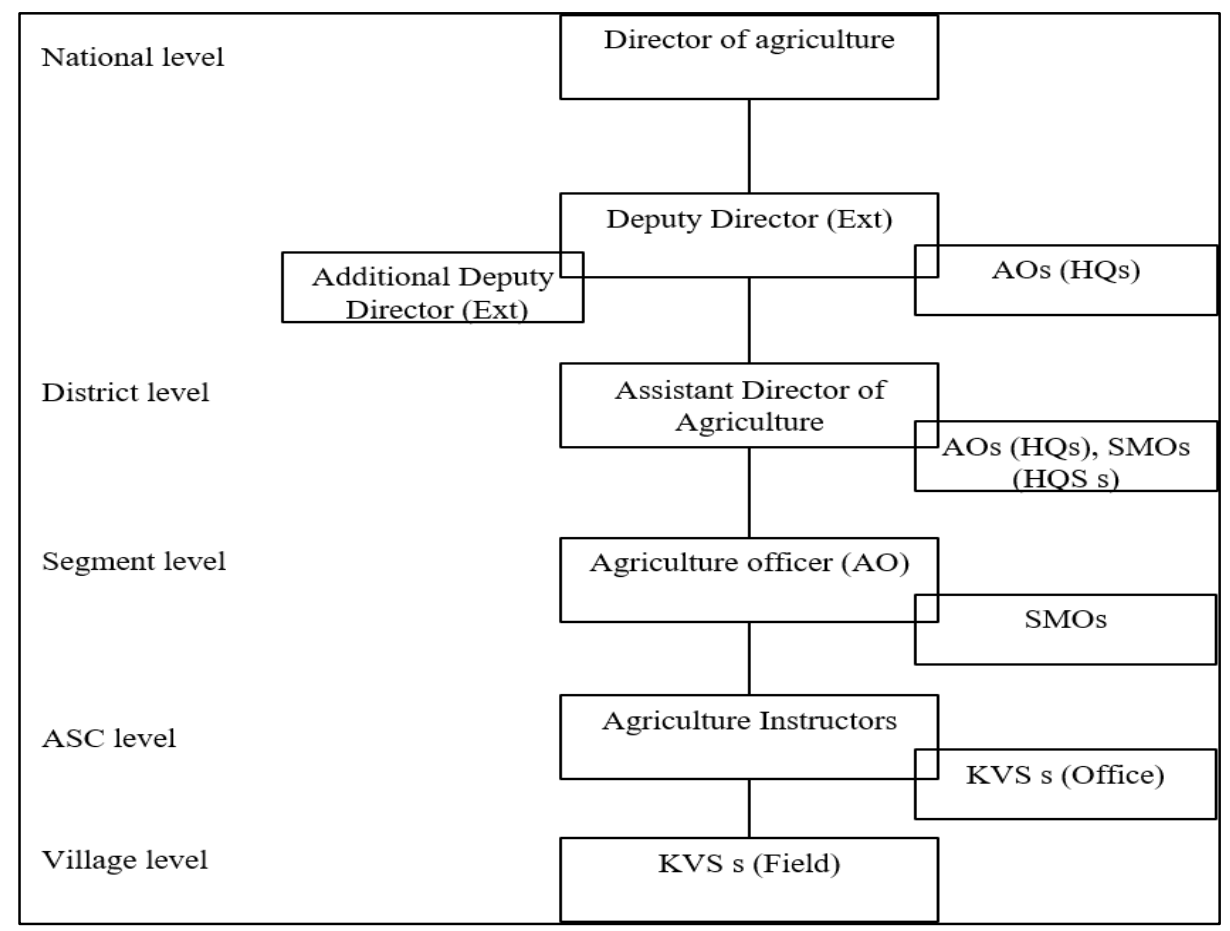

Figure A1: The Sri Lankan extension framework, 1980 Source: Abeywardena (1984). 